\title{
Стручне информације
}

\section{„ПОДУЧАВАНЕ КАРАКТЕРА И КРЕИРАНЕ ПОЗИТИВНЕ УЧИОНИЦЕ“ (TEACHING CHARACTER AND CREATING POSITIVE CLASSROOMS)}

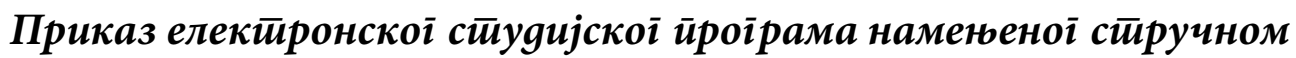

\author{
усавриавању настиавника из целої светиа
}

Програм „Подучавање карактера и креирање позитивне учионице“ Релеј факултета за образовање из Њујорка (Relay Graduate School of Education), који води Дејв Левин (Dave Levin), дизајниран је да одговори на потребу данашње школе за ефикасним и успешним наставницима. Може се похађати бесплатно, на енглеском језику, преко портала Курсера (Coursera). Преко овог портала, иначе, могуће је бесплатно похађати програме бројних образовних институција из различитих крајева света, на различитим језицима. Циљ програма „Подучавање карактера и креирање позитивне учионице“ јесте да полазнике (педагоге, наставнике, родитеље, студенте...) припреми за интегрисање подучавања карактера у њихов рад са младима.

\section{Подучавање карактера и} креирање позитивне учионице

Програм траје четири седмице, а у оквиру сваке седмице издвајају се три врсте активности за полазнике:

- Преглед филмова (могуће је прочитати и транскрипте на енглеском језику);

- Вежбе, које треба практиковати у току недеље, а затим поделити на форуму утиске;

- Истраживање (преглед додатног материјала намењеног онима који желе да знају више).

На самом почетку курса тражи се од полазника да двадесет и четири снаге карактера поређају према важности коју имају за успех ученика (овде се намерно говори о снагама карактера, а не о особинама, јер се жели нагласити да су то променљиве категорије, те да се као такве могу подучавати и унапређивати.) Када полазници поређају снаге карактера од најзначајније снаге за успех ученика до најмање значајне, заправо раде анкету ВИА Института за карактер (Via Institute on Charactere). Moгуће је изабрати језик на коме учесници желе да одговарају на питања из анкете. Резултат анкете је лични профил снага карактера, у коме су поређане снаге карактера учесника анкете, од најизраженије до најслабије изражене. Затим, треба упоредити листу снага, коју су полазници курса одредили за ученике, и сопствену листу снага карактера. Резултат упоређивања обично буде такав да наставници за ученике одреде самоконтролу као веома важну снагу карактера за успех, а да се та иста самоконтрола налази веома ниско на њиховој сопственој лествици. То уноси много смеха у групу када се врши анализа. Ми често тражимо од деце да раде ствари у којима не уживају. То не значи да ми то не треба да тражимо, већ, како се наводи на курсу (Seligman, 2009), треба да их питамо да то ураде, са емпатијом.

Сет од двадесет и четири карактерне снаге потиче из истраживања др Мартина Селигмана (Martin Seligman) са Универзитета из Пенсилваније и покојног др Криса Петерсона (Chris Peterson) са Универзитета у Мичигену. Они су утврдили да постоје двадесет и четири црте карактера које, у раз124 
личитим комбинацијама, помажу људима да „цветају“, односно напредују. У својој књизи др Мартин Селигман представио је концепт звани перма. Он сматра да постоји пет елемената који чине „процват“, а када се поређају на одређен начин, дају акроним ПЕРМА:

$$
\begin{aligned}
& \text { П - позитивна емоција } \\
& \text { (роsitive emotion); } \\
& \text { E - ангажман (engagement); } \\
& \mathbf{P} \text { - добри односи (good rela- } \\
& \quad \text { tionships); } \\
& \text { M - смисао и сврха (meaning } \\
& \text { and purpose); } \\
& \text { А - подвиг (accomplishment). } \\
& \text { Др Салигман (Seligman, 2009) }
\end{aligned}
$$
верује да, ако повећамо ПЕРМУ у учионици, повећавамо и успех ученика у школи, и обрнуто. Када успех ученика расте, повећава се и ПЕРМА. Овај програм је у великој мери усмерен на праксу. Има много задатака усмерених на развијање карактерних снага. Ово су само неки од примера тих интересантних вежби:

- Вежба „Три добре ствари“, помоћу које је могуће развијати оптимизам, коју су креирали Мартин Салигман и саp. (Martin Seligman et al.), тражи од учесника курса да сваки дан у току једне недеље (идеално после вечере и пре спавања) запишу три добре ствари које су им се десиле у току дана.

- Вежбе које доприносе развијању захвалности:

1. Требало би у току недељу дана направити додатни напор и исказати признање људима који су то својим поступци- ма заслужили, било да су то чланови породице или пријатељи, сарадници... Притом, није довољно рећи само „хвала“, већ је пожељно навести конкретно за шта смо им захвални.

2. Писање писма захвалности особи у нашем животу којој се никада нисмо адекватно захвалили, а требало је. Захвалност се може изразити и за велике и за мале ствари.

(Овде морам признати да је резултат ове вежбе било једно дивно, емотивно и дирљиво искуство - радосно и тужно, истовремено.)

- Вежба практиковања истинског осмеха, када је то прикладно, тврди се на овом курсу, утиче на наш полет и ентузијазам, као и на ентузијазам наших сарадника. Људе са којима смо у интеракцији: колеге, ученике, комшије, пред касом и слично, треба поздравити срдачно, са осмехом. Требало је након практиковања ове вежбе размислити и исказати како аутентичан осмех делује на нас и на оне који су њиме били погођени.

- „Немојте да угрозите Ваше позитивне коментаре пратећи их са речју 'али'!“, савет је вежбе која доприноси развијању социјалне интелигенције. Реч „али“, сматра Шели Гејбл (Shelly Gable), може негирати сваку мисао и осећање које јој претходи. Дакле, треба избацити „али“ из свог речника и заменити га паузом. На пример, уместо да кажемо: „ја разумем шта сте рекли, али мислим да би требало...., треба рећи: „Разумем шта хоћете да кажете. Мислим да би требало...“" (Гејбл).

Ове вежбе се практикују у току седмице, а након тога следи рефлексија на форуму. Полазници курса извештавају о исходима које су вежбе имале на њих саме и на људе који су ступали са њима у интеракцију.

Све ове вежбе, иначе, представљају такозване микромоменте и на дневној основи служе јачању снага и вештина карактера. Микромоменат је сваки тренутак у коме можемо оснажити однос са другом особом. Данијел Канеман (Daniel Kahneman, 2002), који је добио Нобелову награду за примену психолошког истраживања и доношење одлука на пољу економије, у суштини је показао да су наша сећања заснована на ситним тренуцима. Наш мозак, како сматра овај аутор, слаже тренутке у три категорије: добро, лоше и неутрално. Али ми се не сећамо оних неутралних момената, већ само оних означених као „добро“ и, наравно, оних означених са „лоше“. Циљ је повећати број позитивних момента. „На крају крајева, наша деца треба да акумулирају више добра него лошег, више позитивног него негативног, у циљу процвата“ (Daniel Kahneman, 2002: 2-1). Канеман је доказао да субјективно благостање заправо повећава продуктивност, креативност, здравље, као и способност достизања циљева. Он напомиње да неће свака интеракција бити позитивна, али је важно да, када деца оду кући, понесу 
више позитивних утисака из школе. Нико не покушава да створи неку врсту лажне пријатности.

Како се у програму наводи, када дајемо повратну информацију ученику, веома је важно оно што кажемо, али важан је и тон нашег гласа и говор нашег тела. Овде се прави фина разлика између различитих повратних информација које наставник даје ученику. Постоје четири врсте повратних одговора на учеников рад: конструктиван пасиван, конструктиван активан, деструктиван пасиван и деструктиван активан одговор. Одговор који покреће на даље ангажовање ученика и који доприноси „цветању“, односно напредовању ученика, јесте онај одговор који је конструктивно активан. Полазници курса се упознају са овим начинима давања повратне информације ученику, а затим, решавајући један тест, показују колико су разумели материју.

у једном филму, у оквиру овог курса, говори се о чланку објављеном 2007. године у коме је описана студија Керол Двек са Стенфорд универзитета (Carol Dweck from Stanford University). Др Двек (Dweck, 2007) анкетирала је триста седамдесет три средњошколца. Поставила је свима једно исто питање, које се односило на то да ли је интелигенција нешто што је фиксно или нешто што се може мењати и развијати. Године су пролазиле и она је приметила да су испитаници групе, која је сматрала да је интелигенција нешто што се не може мењати, лакше и брже одустајали. Суочени са неуспехом, ученици ове групе мислили би да је проблем у њима самима, сумњали би у своје интелектуалне капаците- те и одустајали би. Са друге стране, испитаници који су веровали у то да интелигенција може расти и развијати се, они су при суочавању са неуспехом били више заинтересовани за учење и били су спремни да преузму ризик и онда када греше. Они су били спремни да напорно раде, јер су веровали да могу боље. Мењали су стратегије и покушавали би изнова. Грешке и неуспехе видели би као прилику да нешто науче, побољшају се, даље развијају и „расту“. Овде се ради о томе да, ако желимо да имамо раст менталног склопа и да напредујемо, морамо бити фокусирани на напор. Добре стратегије и тражење проактивне помоћи су средства за раст и постигнуће. Али од кључне важности је, како каже др Двек, помоћи деци да разумеју шта је то што су они урадили на путу до успеха како би те стратегије користили и понављали у будућим ситуацијама. Нема ништа лоше у томе рећи ученику да је био истрајан, али је боље рећи да је одлично то што је завршио оно што је започео. Овде се не ради о прецизности изражавања, већ се ради о помоћи деци да идентификују понашања која су демонстрирала развијајући своје способности и снаге.

Овај програм нуди много корисних смерница које потпомажу раст менталног склопа ученика. Ево неких од њих:

- Не можете само рећи детету да се труди, а да му не понудите стратегије које га могу довести до постигнућа и не пружите подршку његовим напорима (Dweck, 2007);

- Важно je да наставници иду у детаље када образ- лажу учеников тачан одговор. Дејвид Доктерман (David Dockterman), ванредни предавач на Харварду (Harvard Graduate School of Education), каже да ученицима не значи много када им наставник само каже: „То је тачан одговор.“Али када наставник тачно наведе шта је то у учениковом одговору што је добро, то је онда модел учења за друге ученике (Доктерман);

- Уместо прозивања првог ученика који подигне руку да одговори на питање, један наставник хемије на академији (SciAcademy) y Њу Орлеансу чека да сви његови ученици подигну руке. Такав приступи ставља фокус на процес учења, а не на брзину и трку за тачним одговором.

Трећа недеља курса посвећена је макроструктури. Макроструктура би била намерно створена структура, односно рутински, експлицитно или имплицитно дизајниран систем усмерен подучавању карактера. Да би била ефикасна, свака макроструктура мора да има четири елемента:

1. понављање, рутину;

2. проактивно планирање;

3. активно учење, делање и

4. ред.

Лекције које се обрађују у школи треба да буду испланиране тако да имају дуплу сврху, тј. два циља: образовни и васпитни. Овај васпитни део може бити експлицитно дат, уз именовање одређене карактерне снаге, а може 126 
бити и имплицитно обрађен. Мејми Хостетер (Mayme Hostetter), декан Релеј факултета, истиче да, ако једном недељно имамо лекцију са дуплом наменом, имаћемо велики број ефективних макроструктура у учионици. Другим речима, изградња карактера је тада уткана у ДНК одељења. Њена теорија је да треба изградити макроструктуру која омогућава ученицима да размисле и дискутују о сопственим карактерним вештинама. Она препоручује коришћење картица за праћење и мерење раста карактера. Требало би у средњој школи ове картице користити на крају сваког квартала, по њеном мишљењу. Истиче и да је важно да то буде природан део школског процеса. Др Хостетер каже да у претходних двеста година међу људима није било никог ко је сматрао да су истрајност, захвалност, ентузијазам и социјална интелигенција погрешне ствари, које деца не треба да уче у школи. Она каже да није срела ниједног родитеља који не би волео да његово дете развије ове вештине карактера. Задатак за крај био је да полазници курса креирају једну макроструктуру, коју ће неколико других полазника процењивати, али коју ће и сами процењивати на основу унапред датих критеријума.

Сматрам да изградњу карактера можемо на различите начине имплементирати у наставну праксу, како кроз обавезне и изборне предмете, тако и кроз рад одељенске заједнице. Ученике можемо упознати постепено са свим вештинама карактера како би сами ученици тумачили и разумели поступке своје и туђе, али и како би пратили сопствени раст и раст својих другара. То можемо чинити кроз лекције дупле намене, али и кроз посебно планиране актив- ности одељенске заједнице. Прича о карактерним снагама може се користити у било којој етапи часа. Могућности и идеја је много.

Верујем да један системски приступ расту карактера наших ученика може допринети стварању једне позитивне климе у одељењу, а можда и шире, а надам се да може допринети и бољем васпитању наше омладине. Зато, топло препоручујем овај курс свим колегама који раде са младима.

\section{Литература}

- https://www.coursera.org/course/ teachingcharacter

- http://www.edweek.org/ew/ articles/2013/09/11/03mindset_ ep.h33.html

Найаша М. Симуновић ОШ „Ђура Даничић“, Београд 